\title{
Silica Particulate Pollution in Central India
}

\author{
Khageshwar Singh Patel ${ }^{*}$, Sapana Gupta1, Shobhana Ramteke1, \\ Keshaw Prakash Rajhans ${ }^{1}$, S. Nava ${ }^{2}$, F. Lucarelli ${ }^{2}$ \\ ${ }^{1}$ School of Studies in Chemistry/Environmental Science, Pt. Ravishankar Shukla University, Raipur, India \\ ${ }^{2}$ Department of Physics, University of Florence and INFN, via Sansone, Florence, Italy \\ Email: "patelks_55@hotmail.com
}

Received 11 November 2015; accepted 13 February 2016; published 16 February 2016

Copyright (C) 2016 by authors and Scientific Research Publishing Inc.

This work is licensed under the Creative Commons Attribution International License (CC BY).

http://creativecommons.org/licenses/by/4.0/

(c) (i) Open Access

\begin{abstract}
Asbestos exposure is known to cause asbestosis i.e. lung cancer (mesothelioma) with increased risk of diseases i.e. gastrointestinal, colorectal, throat, kidney, esophageal, and gallbladder cancer. Therefore, in the present work, the concentration of $\mathrm{SiO}_{2}$ associated to the coarse and fine particulates in the ambient air of most industrialized area of central India i.e. Raipur city (capital of Chhattisgarh state) is described. The concentration of $\mathrm{SiO}_{2}$ in ambient air associated to the $\mathrm{PM}_{10}$ and $P M_{2.5}$ was ranged from 6.6 to 102 and 0.2 to $15 \mu \mathrm{g} / \mathrm{m}^{3}$ with mean value of $30.0 \pm 6.0$ and $4.3 \pm$ $0.8 \mu \mathrm{g} / \mathrm{m}^{3}$, respectively. The seasonal, spatial and temporal variations of $\mathrm{SiO}_{2}$ in the air are described.
\end{abstract}

\section{Keywords}

Ambient Air, Particulate Matter, Silica, Trace Elements

\section{Introduction}

Silica is air toxics when inhaled or ingested during product use, demolition work, building or home maintenance, repair, remodeling, etc. [1]. Exposure to silica containing respirable particulates ( $<0.5$ to $5.0 \mu \mathrm{m}$ in diameter) over long time causes silicosis, lung cancer and airways diseases [1]-[4]. Some investigations of silica exposures were reported [5]-[20]. In the present work, the ambient exposure of silica associated to coarse and fine particulates in the most industrialized area of the central India (Raipur city, capital, Chhattisgarh state) is described.

\section{Methods and Materials}

\subsection{Study Area}

The Raipur city (latitude: $21^{\circ} 24^{\prime} \mathrm{N}$ and longitude: $81^{\circ} 63^{\prime} \mathrm{E}$ ), capital of Chhattisgarh state, India, was selected for ${ }^{*}$ Corresponding author. 
the present study due to running of several industries in this region. The population of city including suburb area is $\approx 2$ million, and being an important regional commercial and industrial destination for the coal, power, steel and aluminum industries. Several steel and ferro-alloys industries are running in this city.

\subsection{Particulate Collection}

The Partisol Model 2300 Sequential speciation air sampler (Thermo Scientific, USA) was used for collection of the $\mathrm{PM}_{10}$ and $\mathrm{PM}_{2.5}$ samples during period, June 2005 - May 2014. The $\mathrm{PM}_{10}$ and $\mathrm{PM}_{2.5}$ samples were collected simultaneously on 47-mm teflon quoted PTVC filter (Whatmann) housed in molded filter cassettes. One sample blank was used for collection of $\mathrm{PM}_{10}$ and $\mathrm{PM}_{2.5}$. The sampler was installed at the roof of the building, 3-m above from the ground level at residential site: Dagania (no. 2), Raipur, Figure 1. Similarly, PM collection was carried out in the commercial (Jaistambh, no. 3) and industrial area (Siltara, no. 1). The filter was prior heated up to $50^{\circ} \mathrm{C}$ to reduce their blank value, and placed in clean polyethylene petri dish. The weighted filters were housed in the sampler and run for 24-hrs from $6.00 \mathrm{am}-6.00 \mathrm{am}$. The loaded filters were dismounted, brought to laboratory, transferred into the desicator, and finally weighted to record the particulate contents.

\subsection{Analysis}

The elemental analysis of the collected aerosol samples has been carried out by PIXE (Particle Induced X-ray

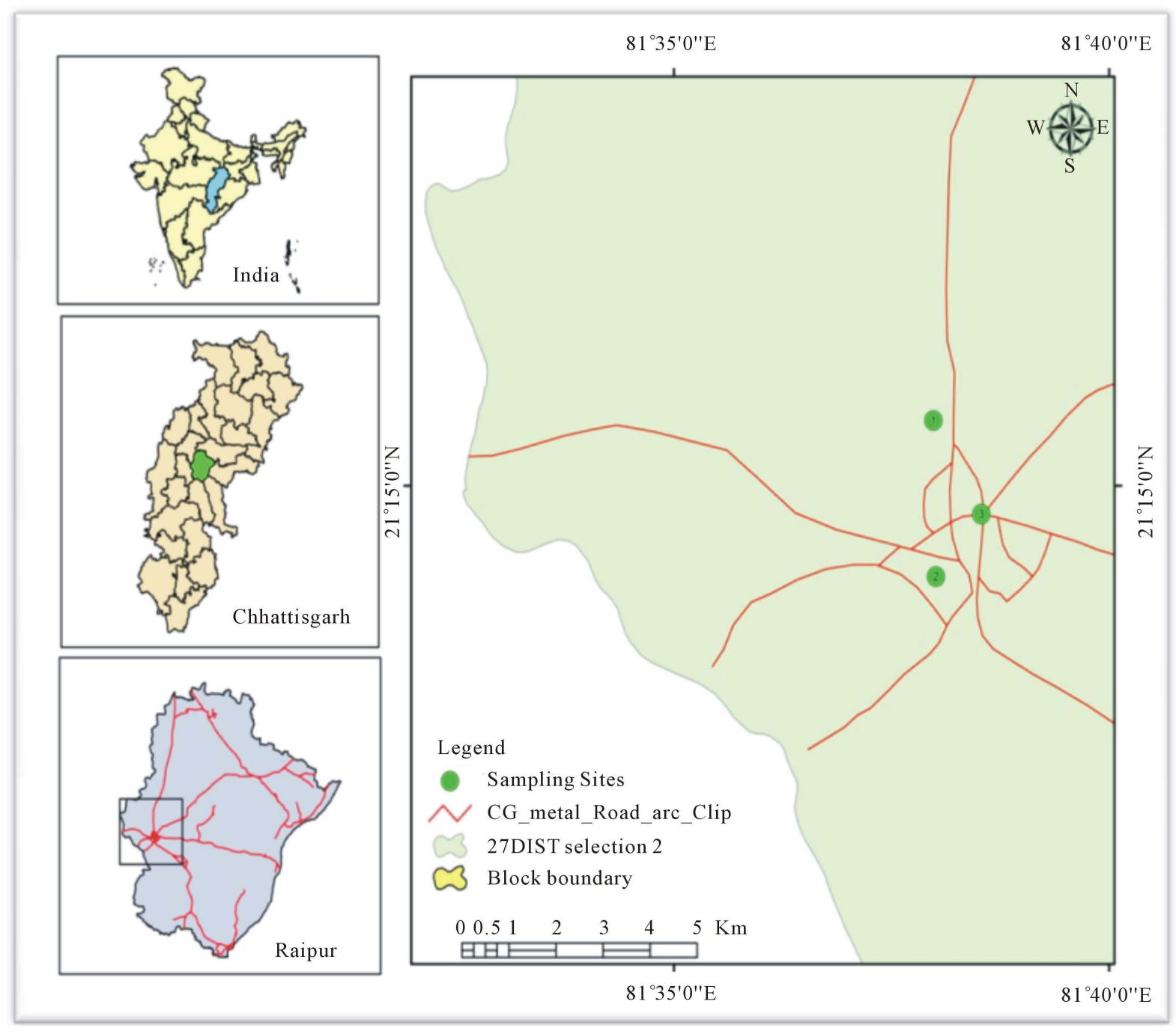

Figure 1. Sampling locations in Raipur city, CG, India. 
Emission) technique, using the external beam set-up of the 3 MV Tandetron accelerator of the LABEC laboratory (INFN) in Florence, Italy.

\section{Results and Discussion}

\subsection{Particulate Concentration}

The annual (June 2005 - May 2006) mass concentrations of $\mathrm{PM}_{10}$ and $\mathrm{PM}_{2.5}(\mathrm{n}=44)$ are in the range 37 - 501 $\mu \mathrm{g} / \mathrm{m}^{3}$ and $19-259 \mu \mathrm{g} / \mathrm{m}^{3}$ with arithmetic mean value of $209 \pm 38 \mu \mathrm{g} / \mathrm{m}^{3}$ and $95 \pm 18 \mu \mathrm{g} / \mathrm{m}^{3}$, respectively, Figure 2. The annual mean ratio of $\left[\mathrm{PM}_{2.5}\right] /\left[\mathrm{PM}_{10}\right]$ was found to be 0.46 . The highest concentration of the $\mathrm{PM}_{10}$ and $\mathrm{PM}_{2.5}$ was observed in the winter season (December - January), may be due to temperature inversion and lowest air mass speed. The lowest seasonal average concentration of $\mathrm{PM}_{10}$ and $\mathrm{PM}_{2.5}$ observed was 50 and $20 \mu \mathrm{g} / \mathrm{m}^{3}$, respectively, could be considered as background levels in Raipur city.

\subsection{Elemental Concentration}

The elements i.e. $\mathrm{Na}, \mathrm{K}, \mathrm{Cl}, \mathrm{Al}, \mathrm{Si}, \mathrm{S}, \mathrm{Ca}$ and $\mathrm{Fe}$ are main constituents of the PM. The annual mean concentration of $\mathrm{Na}, \mathrm{K}, \mathrm{Cl}, \mathrm{Al}, \mathrm{Si}, \mathrm{S}, \mathrm{Ca}$ and $\mathrm{Fe}$ in the ambient air associated to the $\mathrm{PM}_{10}$ was $1.0 \pm 0.1,3.4 \pm 0.6,1.9 \pm$ $0.5,6.6 \pm 1.1,15.9 \pm 2.8,3.4 \pm 0.3,9.8 \pm 1.9$ and $12.7 \pm 2.5 \mu \mathrm{g} / \mathrm{m}^{3}$, respectively, Figure 3 . The concentration of $\mathrm{Na}, \mathrm{K}, \mathrm{Cl}, \mathrm{Al}, \mathrm{Si}, \mathrm{S}, \mathrm{Ca}$ and $\mathrm{Fe}$ in the air associated to the $\mathrm{PM}_{2.5}$ was $0.5 \pm 0.1,1.5 \pm 0.3,0.8 \pm 0.4,1.0 \pm 0.2,2.0$ $\pm 0.4,3.1 \pm 0.4,0.9 \pm 0.2$ and $1.6 \pm 0.4 \mu \mathrm{g} / \mathrm{m}^{3}$, respectively. Silicon and sulfur showed the highest concentration in the $\mathrm{PM}_{10}$ and $\mathrm{PM}_{2.5}$ mode, respectively, Figure 3.

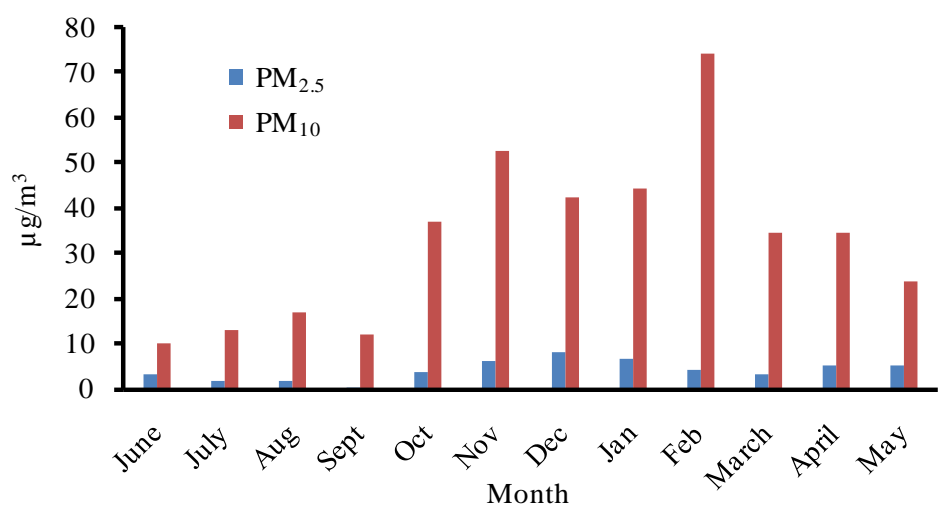

Figure 2. Distribution of $\mathrm{PM}_{10}$ and $\mathrm{PM}_{2.5}$ in the ambient air of Raipur city at residential area during year, June 2005 - May 2006.

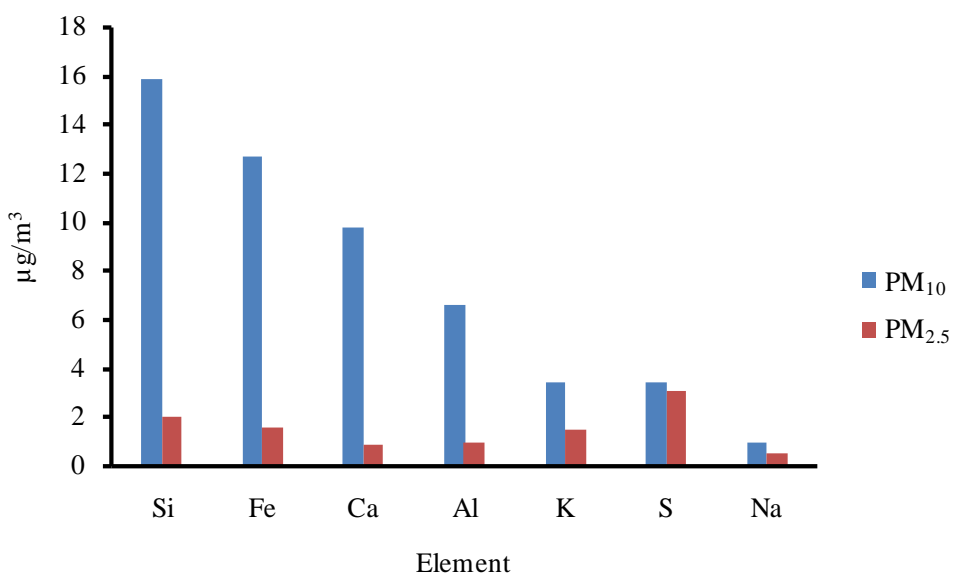

Figure 3. Annual mean concentration of major elements in ambient air associated to the $\mathrm{PM}_{10}$ and $\mathrm{PM}_{2.5}$. 


\subsection{Silica Concentration}

The existence of silicon in the particulates is assumed as silica, $\mathrm{SiO}_{2}$, and a factor of 2.14 was used to compute $\mathrm{SiO}_{2}$ concentration. The $\mathrm{SiO}_{2}$ concentration associated to the $\mathrm{PM}_{10}$ and $\mathrm{PM}_{2.5}$ was ranged from 6.6 - 102 and 0.3 - $15.1 \mu \mathrm{g} / \mathrm{m}^{3}$ with mean value of $40 \pm 6$ and $4.5 \pm 1.0 \mu \mathrm{g} / \mathrm{m}^{3}$, respectively.

\subsection{Seasonal, Spatial and Temporal Variations}

The highest concentration of $\mathrm{SiO}_{2}$ in the particulate phase was observed during month of February, 2006 mainly due to lowest wind speed $(<2 \mathrm{~km} / \mathrm{hr}$ ) and higher temperature inversion, Figure 4 . In turn, the lowest concentration of $\mathrm{SiO}_{2}$ in the air was marked in the month of July due to the highest wind speed ( $>10 \mathrm{~km} / \mathrm{hr}$ ) and heavy rain fall (>50 cm/month). The $\mathrm{SiO}_{2}$ concentration in the commercial area (CA) and industrial area (IA) was increased enormously, Figure 5. The temporal variation of $\mathrm{SiO}_{2}$ was found to increase during year 2006 to 2009 due to vast industrialization, increase in vehicle numbers and unpaved nature of the road, Figure 6. Thereafter, the $\mathrm{SiO}_{2}$ concentration was found to decrease may be due to use of control devices for industrial effluents and improving the road quality.

\subsection{Silica Exposure}

Exposure of silica beyond the threshold limit value (TLV) of $25 \mu \mathrm{g} / \mathrm{m}^{3}$ in air causes respiratory diseases [6]. The annual mean value of silica exposed was $40 \pm 6 \mu \mathrm{g} / \mathrm{m}^{3}$, higher than the TLV value of $25 \mu \mathrm{g} / \mathrm{m}^{3}$. The whole population is exposed with silica at elevated levels during period, October to April of a year.

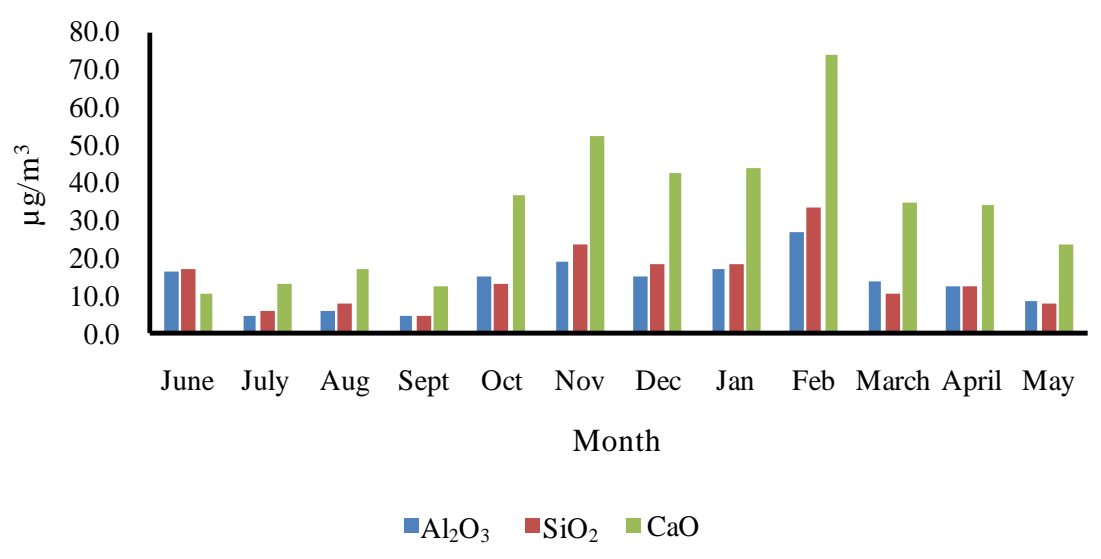

Figure 4. Seasonal variation of oxide of $\mathrm{Al}, \mathrm{Si}$ and $\mathrm{Ca}$.

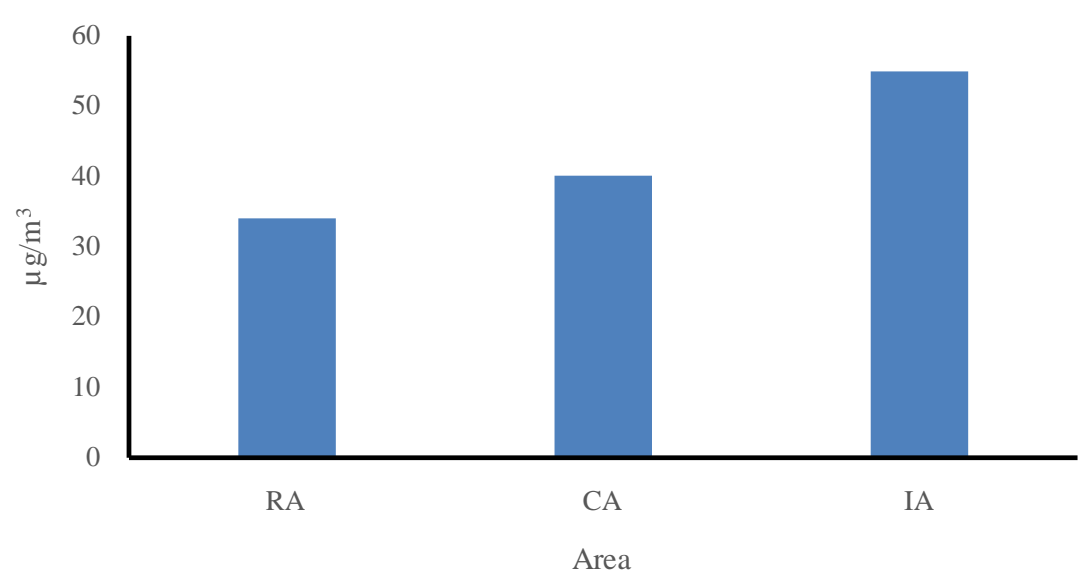

Figure 5. Spatial variation of $\mathrm{SiO}_{2}$ in residential (RA), commercial (CA) and industrial area (IA) of Raipur city during February, 2006. 


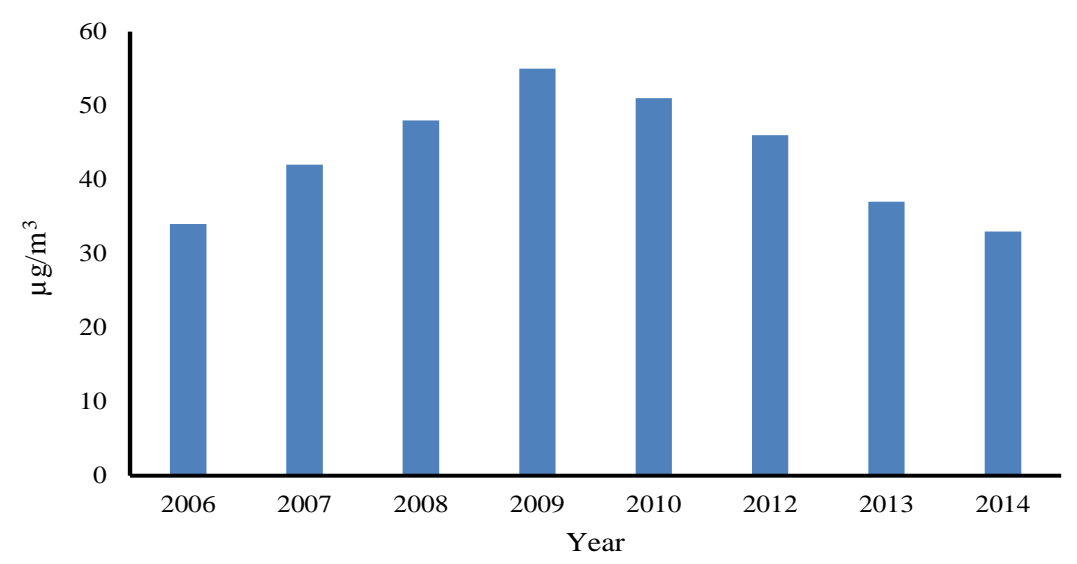

Figure 6. Temporal variation of $\mathrm{SiO}_{2}$ in month of February at residential site of Raipur city.

\section{Conclusion}

The respirable aerosol concentration in the urban environment of India is found several folds higher than permissible limits during period, October - April of a year. They are associated with elevated levels of elements i.e. $\mathrm{Si}, \mathrm{Fe}, \mathrm{Ca}$ and $\mathrm{Al}$. The concentration of silica in the ambient environment of Raipur city, central India was found to be higher than the permissible limit during period, October - April of a year. The mean silica concentration in the $\mathrm{PM}_{10}$ was observed to be $17.5 \% \pm 1.7 \%$.

\section{Acknowledgements}

We are thankful to the DST, New Delhi for granting project grant for aerosol studies in central India.

\section{References}

[1] Yu, M.H. (2001) Environmental Toxicology: Impacts of Environmental Toxicants on Living Systems. CRC Press, Boca Raton, 114-115.

https://www.google.co.in/url?sa=t\&rct=j\&q=\&esrc=s\&source=web\&cd=3\&cad=rja\&uact=8\&ved=0CCwQFjACahUK Ewjhv4br_PjIAhUCI5QKHSmlCbM\&url=http\%3A\%2F\%2F117.3.71.125\%3A8080\%2Fdspace\%2Fbitstream\%2FDH KTDN\%2F6131\%2F1\%2F6473\%2520Environmental\%2520toxicology\%2520Impacts\%2520of\%2520environmental \%2520toxicants\%2520on\%2520living\%2520systems..pdf\&usg=AFQjCNGqZB8YG8Id3SFmoQq1uzVarCJpVw

[2] Dahmann, D., Taeger, D., Kappler, M., Büchte, S., Morfeld, P., Brüning, T. and Pesch, B. (2008) Assessment of Exposure in Epidemiological Studies: The Example of Silica Dust. Journal of Exposure Science and Environmental Epidemiology, 18, 452-461. http://dx.doi.org/10.1038/sj.jes.7500636

[3] NIOSH, Hazard Review (2002) Health Effects of Occupational Exposure to Respirable Crystalline Silica. DHHS Publication No. 2002-129. National Institute for Occupational Safety and Health, Cincinnati. http://www.cdc.gov/niosh/docs/2002-129/pdfs/2002-129.pdf

[4] Lynge, E., Kurppa, K., Kristofersen, L., Malker, H. and Sauli, H. (1986) Silica Dust and Lung Cancer: Results from the Nordic Occupational Mortality and Cancer Incidence Registers. Journal of the National Cancer Institute, 77, 883-889.

[5] Yassin, A., Yebesi, F. and Tingle, R. (2005) Occupational Exposure to Crystalline Silica Dust in the United States, 1988-2003. Environmental Health Perspectives, 113, 255-260. http://dx.doi.org/10.1289/ehp.7384

[6] Flanagan, M.E., Seixas, N., Majar, M., Camp, J. and Morgan, M. (2003) Silica Dust Exposures during Selected Construction Activities. AIHA Journal: A Journal for the Science of Occupation and Environmental Health and Safety, 64, 319-328. http://dx.doi.org/10.1080/15428110308984823

[7] Flynn, M.R. and Susi, P. (2003) Engineering Controls for Selected Silica and Dust Exposures in the Construction Industry-A Review. Applied Occupational and Environmental Hygiene, 18, 268-277. http://dx.doi.org/10.1080/10473220301406

[8] Akbar-Khanzadeh, F. and Brillhart, R.L. (2002) Respirable Crystalline Silica Dust Exposure during Concrete Finishing (Grinding) Using Hand-Held Grinders in the Construction Industry. The Annals of Occupational Hygiene, 46, 341-346. http://dx.doi.org/10.1093/annhyg/mef043 
[9] Calzolai, G., Chiari, M., Garcia-Orellana, I., Lucarelli, F., Migliori, A., Nava, S. and Taccetti, F. (2006) The New External Beam Facility for Environmental Studies at the Tandetron Accelerator of LABEC. Nuclear Instruments and Methods in Physics Research Section B: Beam Interactions with Materials and Atoms, 249, 928-931. http://dx.doi.org/10.1016/j.nimb.2006.03.193

[10] Mouli, P.C., Mohan, S.V., Balaram, V., Kumar, M.P. and Reddy, S.J. (2006) A Study on Trace Elemental Composition of Atmospheric Aerosols at a Semi-Arid Urban Site using ICP-MS Technique. Atmospheric Environment, 40, 136-146. http://dx.doi.org/10.1016/j.atmosenv.2005.09.028

[11] Balachandran, S., Meena, B.R. and Khillare, P.S. (2000) Particle Size Distribution and Its Elemental Composition in the Ambient Air of Delhi. Environment International, 26, 49-54. http://dx.doi.org/10.1016/S0160-4120(00)00077-5

[12] Sharma, M. and Maloo, S. (2005) Assessment of Ambient Air $\mathrm{PM}_{10}$ and $\mathrm{PM}_{2.5}$ and Characterization of $\mathrm{PM}_{10}$ in the City of Kanpur, India. Atmospheric Environment, 39, 6015-6026. http://dx.doi.org/10.1016/j.atmosenv.2005.04.041

[13] Mukhopadhyay, K., Ramalingam, A., Ramani, R., Dasu, V., Sadasivam, A., Kumar, P., Prasad, S.N., Sambandam, S. and Balakrishnan, K. (2011) Exposure to Respirable Particulates and Silica in and around the Stone Crushing Units in Central India. Industrial Health, 49, 221-227. http://dx.doi.org/10.2486/indhealth.MS1207

[14] Semple, S., Green, D.A., McAlpine, G., Cowie, H. and Seaton, A. (2008) Exposure to Particulate Matter on an Indian Stone-Crushing Site. Occupational and Environmental Medicine, 65, 300-305. http://dx.doi.org/10.1136/oem.2007.032805

[15] Bujak-Pietrek, S., Mikołajczyk, U., Szadkowska-Stańczyk, I. and Stroszejn-Mrowca, G. (2008) Occupational Exposure to Silica Dust by Selected Sectors of National Economy in Poland Based on Electronic Database. Medycyna Pracy, 59, 203-213.

[16] Akbar-Khanzadeh, F., Ames, A., Bisesi, M., Milz, S., Czajkowski, K. and Kumar, A. (2012) Particulate Matter (PM) Exposure Assessment-Horizontal and Vertical PM Profiles in Relation to Agricultural Activities and Environmental Factors in Farm Fields. Journal of Occupational and Environmental Hygiene, 9, 502-516. http://dx.doi.org/10.1080/15459624.2012.695216

[17] Kurmi, O.P., Semple, S., Steiner, M., Henderson, G.D. and Ayres, J.G. (2008) Particulate Matter Exposure during Domestic Work in Nepal. The Annals Occupational Hygiene, 52, 509-517. http://dx.doi.org/10.1093/annhyg/men026

[18] Cavariani, F., Bedini, L., De Rossi, M., Papandrea, F., Carai, A. and Cacchioli, G. (2006) Exposure to Crystalline Silica in the Air during Renovation of Residential Buildings. Giornale Italiano Medicina del Lavoro ed Ergonomia, 28, 209-210.

[19] Hicks, J. and Yager, J. (2006) Airborne Crystalline Silica Concentrations at Coal-Fired Power Plants Associated with Coal Fly Ash. Journal of Occupational and Environmental Hygiene, 3, 448-455. http://dx.doi.org/10.1080/15459620600802747

[20] Beaudry, C., Lavoué, J., Sauvé, J.F., Bégin, D., Senhaji Rhazi, M., Perrault, G., Dion, C. and Gérin, M. (2013) Occupational Exposure to Silica in Construction Workers: A Literature-Based Exposure Database. Journal of Occupational and Environmental Hygiene, 10, 71-77. http://dx.doi.org/10.1080/15459624.2012.747399 